\title{
Genetic algorithm based approach for optimizing the energy rating on existing buildings
}

\author{
Building Services Engineering Research and Technology \\ Fresco Contreras, Rafael; University of Seville, Graphic Expression and Building Engineering \\ Moyano, Juan; University of Seville, Graphic Expression and Building Engineering \\ Rico, Fernando; University of Seville, Graphic Expression and Building Engineering
}

Keywords: Genetic Algorithm, Energy rating, Building energy retrofit measures, Energy saving

\begin{abstract}
The problem of improving the energy behaviour of existing buildings is a current topic of interest in scientific research. In recent years, Public Administrations have made an effort to introduce norms that help to reorient the tendency toward increasing energy consumption by buildings. To do so, manufacturers have developed numerous energy efficiency measures that have become widely extended. The main problem when selecting one or various measures is to identify the ones that will provide the best tradeoff between services and implementation costs. This paper presents a study focused on implementing techniques for calculating the heating and cooling energy demand, along with genetic algorithm, to optimize the process of adjusting the building's energy efficiency rating to a determined rating for existing building. The proposed optimization approach is applied to a real case to demonstrate its validity in a real world situation.
\end{abstract}

\section{Practical application}

This paper presents an innovative method for the building energy-retrofit process. By applying a simple genetic algorithm, the aim is to optimize the cost of intervening in an existing building by fixing the energy rating obtained at a given value. The practical potential of the method presented here is quite extensive, with its greatest exponent being its use by technicians who are unfamiliar with optimization processes. The application of this calculation methodology would simplify the study of projects in the phase of selecting energy-saving measures, given that there are currently many of them, with their independent characteristics, which makes the selection process a slow and ineffective task.

In addition, the method's intuitive interface and the fact that it is programmed in MS Excel make it an innovative method with great applicability in the field of building process optimization. 


\section{Introduction}

The new policies to combat climate change, stemming from the establishment of the Kyoto Protocol and motivated by the increase in energy dependence in some regions (the European Union, for example [1]), are oriented toward reducing energy consumption and the emission of greenhouse gases into the atmosphere. In Europe, Directive 2010/31/EU [2], which replaced Directive 2002/91/CE (EPBD) [3], establishes the milestones to be reached in order to achieve the emission commitments agreed upon for the year 2020. Buildings have an important weight in the overall computation of greenhouse gas emissions, mainly $\mathrm{CO}_{2}[2,4]$. The current legislation requires both newly constructed buildings and, especially, existing ones to meet a series of minimums with regard to their energy behaviour. Thus, there is an attempt to not only detain the increase in the energy demand of the society, but also to reduce it. In turn, the Member States of the European Union have the obligation to take the necessary measures so that the objectives established by the community normative can be met, including the achievement of zero energy buildings [2].

In recent years, the construction field has been the object of numerous studies with the purpose of minimizing energy consumption [5]. Designing building energy retrofit strategies is an arduous task, given that the building itself is an organism composed of many systems and subsystems that directly influence its energy consumption [6]. In addition, the role played by the users in the behaviour of the installations is a determining factor in their efficiency [7].

Initially, in the 1980s, the computational optimization process was applied to the design of new buildings and their operational conditions, in order to maximize their efficiency. Later, in the 1990s and the first decade of the 21 st century, the scope of action of these techniques was broadened to include their application in the energy retrofit process of existing buildings [8]. Currently, this process is an alternative for designing energy retrofit strategies with a high application potential, given that in only one step we achieve the maximum results for certain conditions, thus facilitating the work of the decision maker. 
Traditionally, different types of dynamic thermal simulation software have been used, combined with optimization processes. The main inconvenience of this method is its high computational cost, due to the numerous interactions required to achieve an optimization that meets all the proposed restrictions [9].

\section{Overview and background}

To achieve the optimization of the energy retrofit process, we can draw on various methods, which, according to [10], are classified as Direct Search Methods (Pattern Search [11], Linear Programming [12] and Non-Linear Programming), Evolutionary Algorithms (Genetic Algorithm [13], Evolutionary Programming [14], Genetic Programming [15], Covariance Matrix Adaption Evolutionary Strategy [16] and Differential Evolution [17]) and Meta-heuristic Algorithm (Harmony Search [18], Particle Swarm Optimization [19], Ant Colony Optimization [20] and Simulated Annealing [21]).

Of all of these methods, the most common is the Genetic Algorithm (GA), which uses the principle of natural selection to reach the optimal result. One of the reasons for its popularity is that it is capable of efficiently handling non-linear problems with discontinuities and a large number of local minimums and maximums [22].

The GA was first applied in newly constructed buildings, affecting their form, spaces, materials, etc. In [23], Znouda et al. develop a procedure to optimize the design of buildings in the Mediterranean area. In [24], Rakh and Nassar present a methodology that tries to optimize the shape of the roof to achieve uniformity in the entrance of sunlight on a given day.

Gradually, authors have been extending its application to the energy retrofit process, oriented toward meeting objectives such as minimizing energy consumption. Juan Y [9] shows an in-line decision method that seeks to facilitate the evaluation of the state of the building, in addition to proposing energy building retrofit strategies to achieve a trade-off between the cost and quality factors. Coley and Schukat [25] combine a GA using the variables thermal conductivity of the wall materials and the thermal inertia of each area of the building, with human value judgments (architectural attractiveness). Mazan and Pinto [26] present a method that tries to minimize the energy consumption in heating and 
the hours of artificial lighting, through the design of shade elements. Sahu et al. [27] design the HVAC system (heating, ventilation and air conditioner) in a tropical climate by combining the admittance method and a genetic algorithm. Jin and Overend [28] present an alternative procedure in which they try to optimize an exterior wall by improving the social, environmental and economic values of the building, adjusting its execution cost. Malatji et al. [29] use a multi-objective GA to maximize energy saving after carrying out an energy retrofitting of a building, while managing to minimize the period of return on the initial investment made. Shao et al. [30] present a model based on GA that tries to optimize the energy retrofitting of existing buildings by minimizing three objectives: annual emissions, operational energy consumption and initial investment.

In addition to GA, other optimization methods have been applied in energy building retrofitting, although less frequently. In [31] Asadi et al. apply Tchebycheff Programming to minimize the building's energy consumption by modifying the thermal envelope and spaces.

The common thread in all the articles mentioned is the attempt to optimize certain factors, always minimizing the cost of implementing the energy building retrofit strategies required for this purpose.

Using MS Excel [32] programming, the present study simplify a multi-criteria optimization approach into a GA based mono-criteria optimization approach applied to the heating and cooling energy demand ratings, basing on ISO 13790 [33] and EN 15217 [34]. We chose MS Excel because it is a widely used software that is easy for the average user to handle. The purpose is to optimize, through GA, the execution costs necessary to reach a certain energy efficiency rating for the selected building. The proposed methodology is applied in a case study to demonstrate its robustness and functionality. Regarding the energy building retrofit strategies used in the case study, passive methods are contemplated, given that the purpose is to adjust the energy demand. The decision variables are the type of thermal insulation on external walls and roofs, as well as their thickness, the material of window frames and glass, and the shade factor provided by solar protection devices.

The next section of the article continues with the formulation of the problem and the approach for resolving it. In section 4 , the proposed approach is applied to a real case. 
Finally, section 5 presents the conclusions of the study and proposes new lines of research that can emerge from it.

\section{The proposed GA based mono-criterion approach}

The methodology proposed by ISO 13790 was implemented to determine the heating and cooling energy demands, along with EN 15217, referring to the energy rating of buildings, in MS Excel. The main reason we selected this software is because it can be applied easily by technicians with no specific knowledge in the area of optimizing problems with several variables. This strengthens the reach of the methodology presented, bringing it closer to the professional sector, which is more familiar with MS Excel than with other more specific software like MATLAB.

The GA included in the MS Excel Solver Tool [35] was used to launch the optimization, due to the broad search space that contemplates this problem (see point 4.2.). It is a simple-objective GA, that is, a nondeterministic method. Starting with an initial population (possible combinations of the configured variables), it randomly applies the operators of mutation, crossover and selection (based on the principles of the Theory of Evolution by C. Darwin), which modify this population and create new individual ones (possible solutions). These operators are iteratively applied until the problem converges, thus finding the optimal solution in this calculation process. This solution can differ if the calculation is run again, as it is a nondeterministic method, but both solutions will be close to the optimal one.

The calculation method established by ISO 13790 is contrasted and verified, so that the results obtained are valid for studying buildings in terms of energy. 


\subsection{Decision process}

The decision-making method presented is structured as a process composed of 7 steps, as Figure 1 shows:

Step 1. The user establishes the specific energy rating that he/she wants to achieve.

Step 2. Initial energy rating, based on the structural, occupational and functional characteristics of the building.

Step 3. If the resulting rating is the one desired, no intervention will be necessary; otherwise, the necessary interventions will be planned.

Step 4. The inputs are established (desired energy rating, energy building retrofit strategies...), and the evolutionary optimization process is begun. The result obtained will be the new energy demand values and their corresponding rating, as well as the energy building retrofit strategies selected in each case.

Step 5. Check the ratings obtained and the costs associated with achieving them.

Step 6. If the resulting ratings are acceptable and the execution cost falls within the limits established by the user, the process is over. If any of the three conditions are not acceptable, the restrictions are again established, and the optimization is launched another time.

Step 7. Report on the optimal solution, indicating the modification made in the characteristic energy aspects of the building.

\subsection{Decision model}

ISO 13790 establishes that the demands for heating ( $\left.\mathrm{Q}_{\mathrm{H}, \mathrm{nd}}\right)$ and cooling ( $\mathrm{Q}_{\mathrm{C}, \mathrm{nd}}$ ), in conditions of continuous heating and cooling, are defined by:

$$
\begin{aligned}
& Q_{H, n d}=Q_{H, h t}-\eta_{H, g n} Q_{H, g n} \\
& Q_{C, n d}=Q_{C, g n}-\eta_{C, l s} Q_{C, h t}
\end{aligned}
$$


Figure 1. Decision process diagram.

1

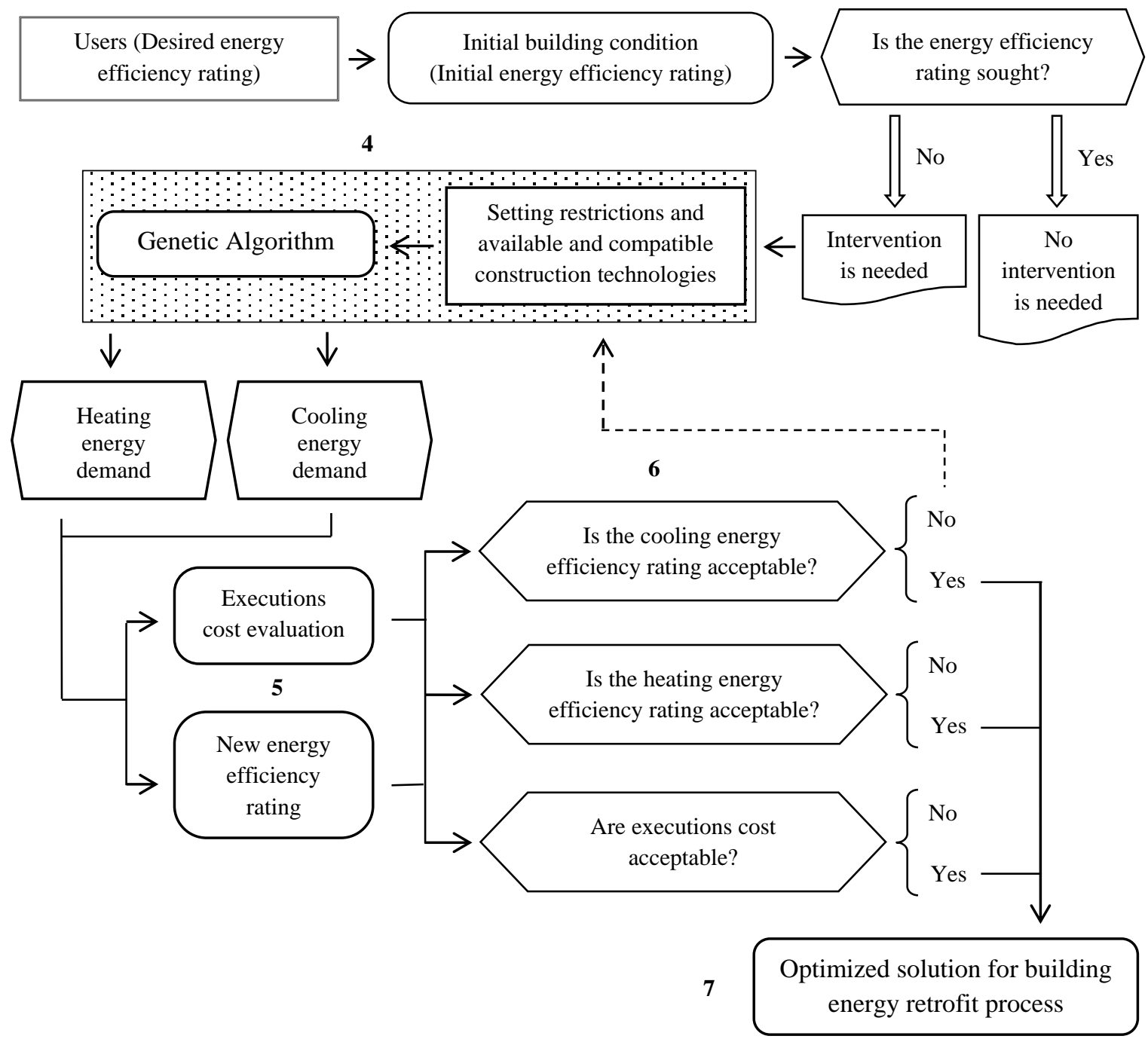

Depending on the climate where the analysed building is located, one demand could not take into account. For example, in Norway, only heating demand will be taken into account, as there is no need for cooling. The opposite would occur with countries such as Panama. In most cases, both demands would be taken into account, as in the study example presented in this paper.

With $\mathrm{Q}_{\mathrm{H}, \mathrm{ht}}$ and $\mathrm{Q}_{\mathrm{c}, \mathrm{ht}}$ being the heating loads for the heating and cooling modes, respectively; $\eta_{\mathrm{H}, \mathrm{gn}}$ and $\eta_{\mathrm{C}, \mathrm{ls}}$ are non-dimensional factors of use of heating and cooling loads; and $\mathrm{Q}_{\mathrm{H}, \mathrm{gn}}$ and $\mathrm{Q}_{\mathrm{C}, \mathrm{gn}}$ are the total calorie gains in heating and cooling systems. 


$$
\begin{aligned}
& Q_{h t}=Q_{T R}+Q_{V E} \\
& Q_{g n}=Q_{I N T}+Q_{S U N}
\end{aligned}
$$

Where $Q_{T R}$ is the heat transferred by transmission, $Q_{V E}$ is the heat transferred by ventilation, $Q_{I N T}$ represents the internal gains and $Q_{S U N}$ the gains due to solar radiation. In the calculation of these factors, many variables are involved. We take into account those that have the greatest influence on the energy profile according to ISO 13790, that is, UValue of walls, roofs, windows and floor, or solar protection elements, among others.

\subsubsection{Decision variables}

The mono-criterion decision-making problem is composed of five decision variable groups, defined as:

1. thermal insulation types for facades;

2. thermal insulation types for roofs;

3. frame type in windows;

4. glass type in windows;

5. shade factor.

Thermal insulation types for facades and roofs are defined according to their thermal conductivity, $\mathrm{k}(\mathrm{W} / \mathrm{mK})$, and their respective thicknesses (in meters). The materials for window frames and glass are defined according to their $\mathrm{U}$-value $\left(\mathrm{W} / \mathrm{m}^{2} \mathrm{~K}\right)$. The shade factor is provided by standard data from typical buildings in Andalusia (nondimensional).

The definition of variables is based on the methodology introduced by Diakaki et al. in [36] and [37]. This research differs from previous ones in that this method orients the optimizations toward achieving a particular energy efficiency rating and not only to optimizing different criteria.

Including I types of thermal insulation materials for facades, we can establish binary variables $\mathrm{X}_{1 \mathrm{i}}$, with $\mathrm{i}=1,2,3, \ldots, \mathrm{I}$. The variables will be defined by:

$$
X_{1 i}=\left\{\begin{array}{l}
1 \rightarrow \text { if facadeinsulation material type } i \text { is selected } \\
0 \rightarrow \text { otherwise }
\end{array}\right\}
$$




$$
\sum_{i=1}^{I} X_{1 i}=1
$$

In the case of thermal insulation for roofs, the variable will have similar properties to the previous ones, with, in this case, $\mathrm{J}$ types of thermal insulation materials. The binary variable will be $X_{2 j}$, where $j=1,2,3, \ldots, J$. From the above, it can be derived that:

$$
\begin{aligned}
& X_{2 j}=\left\{\begin{array}{l}
1 \rightarrow \text { if roof insulation material type } j \text { is selected } \\
0 \rightarrow \text { otherwise }
\end{array}\right\} \\
& \sum_{j=1}^{J} X_{2 j}=1
\end{aligned}
$$

For $\mathrm{K}$ types of window frames, we can define binary variables of the type $\mathrm{X}_{3 \mathrm{k}}$, where $\mathrm{k}=$ $1,2,3, \ldots, \mathrm{K}$. The variables will be defined by:

$$
\begin{aligned}
& X_{3 k}=\left\{\begin{array}{l}
1 \rightarrow \text { if window frame typek is selected } \\
0 \rightarrow \text { otherwise }
\end{array}\right\} \\
& \sum_{k=1}^{K} X_{3 k}=1
\end{aligned}
$$

As in the case of the frames, there are various window glass types. Having L glass types, we can establish binary variables of the type $\mathrm{X}_{41}$, where $1=1,2,3, \ldots$, L. The variables will be defined by:

$$
\begin{aligned}
& X_{4 l}=\left\{\begin{array}{l}
1 \rightarrow \text { if } \text { glass type } k \text { is selected } \\
0 \rightarrow \text { otherwise }
\end{array}\right\} \\
& \sum_{l=1}^{L} X_{4 l}=1
\end{aligned}
$$

Finally, to establish the solar factor values yielded by the shade elements, those classified as "vertical protruding obstacles" by ISO 13790 are selected. In this norm, the G6 table indicates the values this variable takes depending on the latitude where the building is located, the angle of inclination of the shading element, and the orientation of the surface 
on which it is placed. These elements are set up so that they are only installed in periods when the demand for cooling is positive.

For each facade that might have shade elements (E, SE, S, SO and O), the solar factor will be defined as a non-linear variable established by the values dictated by the norm. Having $M$ shade factors, for each facing we can establish binary variables of type $\mathrm{X}_{5 \mathrm{~m}}$, where $\mathrm{m}=1,2,3, \ldots, \mathrm{M}$. The variables will be defined by:

$$
\begin{aligned}
& X_{5 m}=\left\{\begin{array}{l}
1 \rightarrow \text { if shade factor } m \text { is selected } \\
0 \rightarrow \text { otherwise }
\end{array}\right\} \\
& \sum_{m=1}^{M} X_{5 m}=1 \text { for each orientation }
\end{aligned}
$$

In summary, the space for searching for the optimization process can be broken down into 5 groups of decision variables, within which we find a total of 36 binary variables (indicated in tables 5 to 9) that follow the rules of interdependence indicated in equations (6), (8), (10), (12) and (14).

\subsubsection{Decision constraints}

To reach a certain energy rating, two linear inequality constraints are defined: one for heating and the other one for cooling (equations 15 and 16):

$$
\begin{aligned}
& I_{H_{E A T_{-} 2}} \leq I_{H_{E A T_{-} 1}} \\
& I_{\mathrm{COOL} \__{-} 2} \leq I_{\mathrm{COOL}_{-} 1}
\end{aligned}
$$

Where $I_{C O O L_{-} l}$ and $I_{H E A T_{-} l}$ denote the energy indicators for the desired energy efficiency rating of heating and cooling energy demand (desired value of heating and cooling energy demand), while $I_{C O O L \_2}$ and $I_{H E A T} 2$ will be the indicators obtained after implementing the energy saving measures (value of heating and cooling energy demand after implementing the energy saving measures). All of these factors are calculated according to EN 15217, and they are measured in $\mathrm{kWh} / \mathrm{m}^{2}$ year.

To determine the insulation thickness, it is necessary to create non-linear inequality constraints because they adopt only standardized market values $(0.01$ or $0.02 \mathrm{~m}$, for 
example). This is the case of equation 17 (insulation thickness for facades) and equation 18 (insulation thickness for roofs):

$$
\begin{aligned}
& e_{1 i} \leq e_{1_{-} \max } \\
& e_{2 j} \leq e_{2_{-} \max }
\end{aligned}
$$

The thickness is defined by $e_{1 i}$, where $\mathrm{i}=0.01,0.02,0.03, \ldots, \mathrm{I}$ for the case of external walls, and as $e_{2 j}$, where $\mathrm{j}=0.01,0.02,0.03, \ldots, \mathrm{J}$ for roofs. $e_{\max }$ represents the maximum thickness it is possible to choose because the methodology is applied to existing buildings.

\subsubsection{Decision criteria}

The choice of energy building retrofit strategies is established as a mono-criterion selection. The objective pursued will be to minimize the execution costs of the energy saving measures selected, adjusting the results to a certain energy rating for both cooling and heating.

The cost function is defined as the sum of the costs of thermal insulation for facades (CINS_WALL) and roofs $\left(C_{I N S_{-} R O O F}\right)$, the costs of substituting windows (CWIN_FRAME+GLASS), and the costs of installing the corresponding shading elements $\left(C_{S H A D O W}\right)$.

$$
\begin{aligned}
& C=C_{I N S_{-} W A L L}+C_{I N S_{-} R O O F}+C_{W I N \__{-} \text {FRAME }+ \text { GLASS }}+C_{\text {SHADOW }} \\
& C_{I N S_{-} W A L L}=A_{W A L L} \sum_{i=1}^{I} C_{1 i} X_{1 i} \\
& C_{\text {INS } \_ \text {ROOF }}=A_{\text {ROOF }} \sum_{j=1}^{J} C_{2 j} X_{2 j} \\
& C_{W I N_{-} F R A M E+G L A S S}=A_{W I N}\left(\sum_{k=1}^{K} C_{3 k} X_{3 k}+\%_{G L A S S} \sum_{l=1}^{L} C_{4 l} X_{4 l}\right) \\
& C_{\text {SHADOW }}=A_{W I N} \sum_{m=1}^{M} C_{5 m} X_{5 m}
\end{aligned}
$$

It is established that $A$ represents the surface (in $\mathrm{m}^{2}$ ) of each element, $C_{1 i}$ and $C_{2 j}$ represent the cost $\left(€ / \mathrm{m}^{2}\right)$ of the materials selected to provide thermal insulation on facades and roofs, $C_{3 k}$ and $C_{4 l}$ show the costs $\left(€ / \mathrm{m}^{2}\right)$ of the materials attributable to 
windows, $\%_{G}$ indicates the percentage of window that pertains to glass, and $C_{5 m}$ represents the cost $\left(€ / \mathrm{m}^{2}\right)$ of placing the solar protection elements.

\subsubsection{Decision model}

Based on the variables and decision criteria defined above, the resulting decision model is established as a mono-criterion optimization process, with one decision criterion (equation 24), five variables (equations 5 to 14) and four inequality constraints (equations 15 to 18$)$.

$$
\begin{aligned}
& {[\min ] f(x)=C=A_{\text {WALL }} \sum_{i=1}^{I} C_{1 i} X_{1 i}+A_{\text {WALL }} \sum_{i=1}^{I} C_{1 i} X_{1 i}+A_{R O O F} \sum_{j=1}^{J} C_{2 j} X_{2 j}+} \\
& +A_{W I N}\left(\sum_{k=1}^{K} C_{3 k} X_{3 k}+\%_{G L A S S} \sum_{l=1}^{L} C_{4 l} X_{4 l}\right)+A_{W I N} \sum_{m=1}^{M} C_{5 m} X_{5 m}
\end{aligned}
$$

\section{Example case study}

\subsection{Building description}

For the study, the residential building used has structural characteristics that are very common in the south of Spain. It is a one-story, single-family home (

Figure 2) with a flat roof that serves as a terrace. It is located in the city of Seville, in the

south of Spain, (latitude $45^{\circ} \mathrm{N}$ ), and its construction dates from 1960. The net floor area is $91.0 \mathrm{~m}^{2}$, and its mean height is $2.80 \mathrm{~m}$. Table $1-3$ show the main building characteristics of the thermal envelope. Seville is located in climate zone B4 according to the applicable regulation in matters of energy efficiency in Spain, CTE [38]. The value limits for the heating and cooling demands for this zone are indicated in Table 4.

Table 1. Facade characteristics.

\begin{tabular}{lll}
\hline Orientation & Area $\left(\mathrm{m}^{2}\right)$ & $\begin{array}{l}\text { U-value } \\
\left(\mathrm{W} / \mathrm{m}^{2} \mathrm{~K}\right)\end{array}$ \\
\cline { 1 - 2 } North & 8.70 & \multirow{2}{*}{3.00} \\
\cline { 1 - 2 } South & 38.90 & \\
\cline { 1 - 2 } East & 30.00 & \\
\hline West & 8.70 &
\end{tabular}


Table 2. Roof and floor characteristics.

\begin{tabular}{lll}
\hline Element & Area $\left(\mathrm{m}^{2}\right)$ & $\begin{array}{l}\text { U-value } \\
\left(\mathrm{W} / \mathrm{m}^{2} \mathrm{~K}\right)\end{array}$ \\
\hline Floor & 91.00 & 1.00 \\
\hline Roof & 82.00 & 0.70 \\
\hline
\end{tabular}

Table 3. Window characteristics.

\begin{tabular}{lllll}
\hline Window type & Area $\left(\mathrm{m}^{2}\right)$ & $\begin{array}{l}\text { Glass U-value } \\
\left(\mathrm{W} / \mathrm{m}^{2} \mathrm{~K}\right)\end{array}$ & $\begin{array}{l}\text { Frame U-value } \\
\left(\mathrm{W} / \mathrm{m}^{2} \mathrm{~K}\right)\end{array}$ & Solar factor \\
\hline 1 & 1.20 & 5.70 & 3.00 & 0.82 \\
\hline 2 & 2.10 & & & \\
\hline
\end{tabular}

Figure 2. Schematic plan of ground floor of the case study.

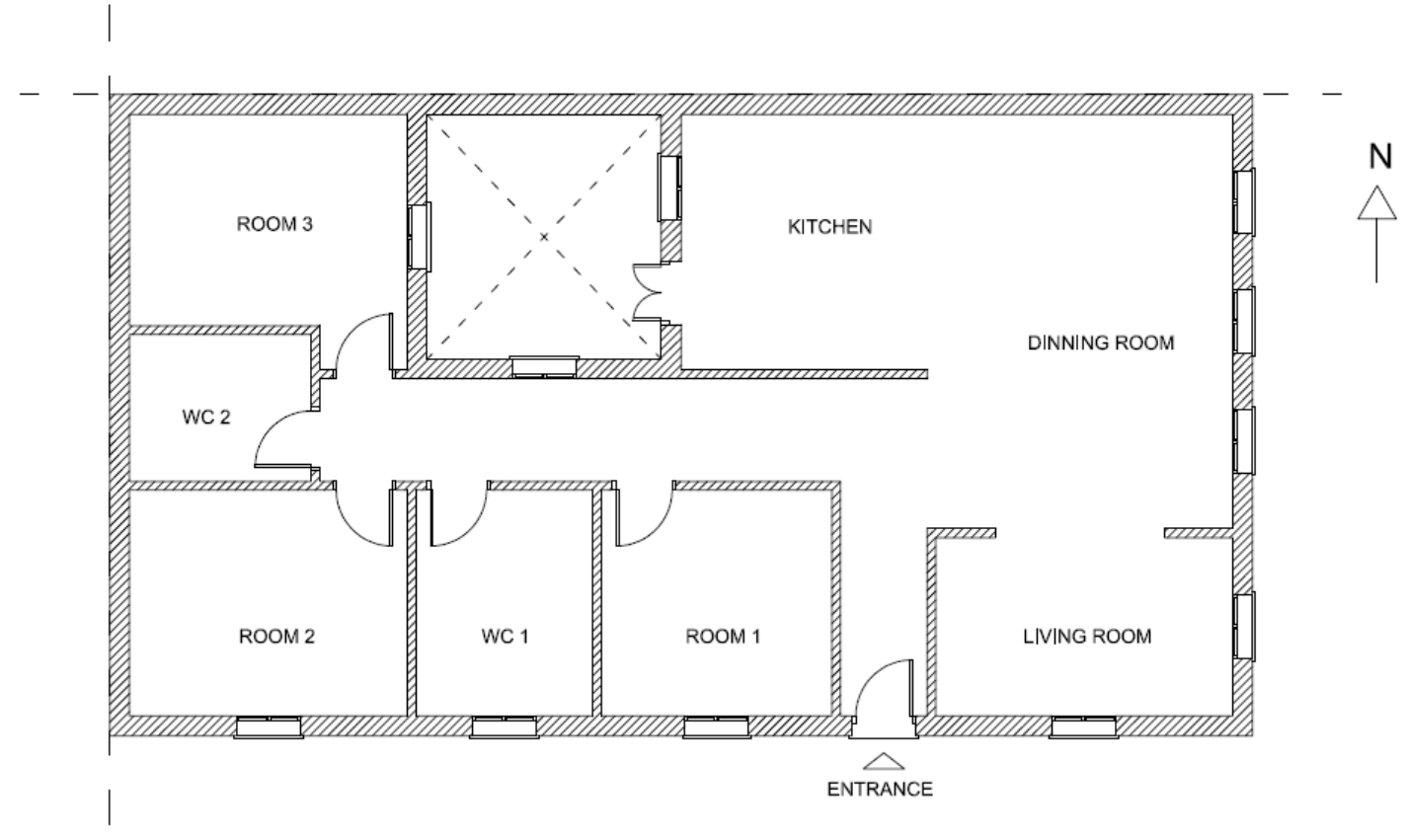

Table 4. Value limits for each energy rating level in the B4 zone.

\begin{tabular}{lcc}
\hline Rating & $\begin{array}{c}\text { Heating demand } \\
\mathrm{kWh} / \mathrm{m}^{2} \text { year }\end{array}$ & $\begin{array}{c}\text { Cooling demand } \\
\mathrm{kWh} / \mathrm{m}^{2} \text { year }\end{array}$ \\
\hline $\mathrm{A}$ & $<8.1$ & $<15.4$ \\
\hline $\mathrm{B}$ & $8.1-15.3$ & $15.4-22.0$ \\
\hline $\mathrm{C}$ & $15.3-25.9$ & $22.0-31.4$ \\
\hline $\mathrm{D}$ & $25.9-41.6$ & $31.4-45.8$ \\
\hline $\mathrm{E}$ & $41.6-64.4$ & $45.8-56.4$ \\
\hline $\mathrm{F}$ & $64.4-79.2$ & $56.4-69.3$ \\
\hline $\mathrm{G}$ & $\geq 79.2$ & $\geq 69.3$ \\
\hline
\end{tabular}


The windows have single-paned glass and metal frames without thermal bridge breaks that represent $20 \%$ of the total surface of window.

There is a centralized heating and cooling system for the entire house, providing service to all the rooms except the bathrooms and kitchen.

The gains due to the people and equipment were established, according to the G.8 table of ISO 13790, at an average of $6 \mathrm{~W} / \mathrm{m}^{2}$ daily, while the index of air infiltration was established at 0.75 air changes/hour.

\subsection{Energy building retrofit strategies}

The cost of installation for each energy building retrofit strategy was calculated using the CYPE rehabilitation price generator database [39]. This is a widely-used, highly prestigious software for the estimation of building projects, both new and retrofitting, in Spain and Latin America.

Different retrofit actions were included that involved facade insulation materials (internal), roof insulation materials (internal and external), window types, and solar protection elements to improve the building's energy demand and thermal comfort in a cost effective manner. The cost of each intervention was calculated taking into account the recovery of the former building conditions, that is, including the costs of all the associated building tasks.

Tables 5 to 9 indicate the characteristics of the different components that make up the decision process. In the case of solar protection, adjustable fixed slats are chosen. These are set at a $60^{\circ}$ to the vertical, the most common setting for the type of building selected in the location mentioned above. 
Table 5. Characteristics of wall insulation materials (WIM).

\begin{tabular}{llllll}
\hline i & Insulation materials & Name & $\begin{array}{l}\text { Thickness } \\
(\mathrm{m})\end{array}$ & $\begin{array}{l}\text { Thermal } \\
\text { resistance } \\
\left(\mathrm{m}^{2} \mathrm{~K} / \mathrm{W}\right)\end{array}$ & $\begin{array}{l}\text { Cost } \\
\left(€ / \mathrm{m}^{2}\right)\end{array}$ \\
\hline 1 & GW (Glass wool) & Wall_Ins_GW_4.5 & 0.045 & 1.25 & 39.21 \\
2 & Self-supporting & Wall_Ins_GW_6.5 & 0.065 & 1.80 & 40.36 \\
3 & & Wall_Ins_GW_8.5 & 0.085 & 2.35 & 42.86 \\
\hline 4 & RW (Rock wool) & Wall_Ins_RW_3.0 & 0.03 & 0.90 & 38.33 \\
5 & Direct & Wall_Ins_RW_4.0 & 0.04 & 1.20 & 42.54 \\
6 & & Wall_Ins_RW_5.0 & 0.05 & 1.50 & 46.07 \\
7 & & Wall_Ins_RW_6.0 & 0.06 & 1.75 & 48.66 \\
8 & & Wall_Ins_RW_8.5 & 0.085 & 2.35 & 53.29 \\
\hline 9 & RW (Rock wool) & Wall_Ins_RW*_4.0 & 0.04 & 1.05 & 38.56 \\
10 & Self-supporting & Wall_Ins_RW*_5.0 & 0.05 & 1.35 & 38.95 \\
11 & & Wall_Ins_RW*_6.0 & 0.06 & 1.60 & 39.37 \\
12 & & Wall_Ins_RW*_7.5 & 0.075 & 2.00 & 40.04 \\
\hline
\end{tabular}

Table 6. Characteristics of roof insulation materials (RIM).

\begin{tabular}{llllll}
\hline $\mathrm{j}$ & Insulation materials & Name & $\begin{array}{l}\text { Thickness } \\
(\mathrm{m})\end{array}$ & $\begin{array}{l}\text { Thermal } \\
\text { resistance } \\
\left(\mathrm{m}^{2} \mathrm{~K} / \mathrm{W}\right)\end{array}$ & $\begin{array}{l}\text { Cost } \\
\left(€ / \mathrm{m}^{2}\right)\end{array}$ \\
\hline 1 & RW (Rock wool) & Roof_Ins_RW_5.0 & 0.05 & 1.25 & 47.64 \\
2 & External & Roof_Ins_RW_7.0 & 0.07 & 1.75 & 53.69 \\
3 & & Roof_Ins_RW_10.0 & 0.10 & 2.55 & 62.74 \\
4 & & Roof_Ins_RW_11.0 & 0.11 & 2.80 & 65.72 \\
\hline 5 & XPS (Extruded & Roof_Ins_XPS_3.0 & 0.03 & 0.85 & 36.96 \\
6 & polystyrene) & Roof_Ins_XPS_5.0 & 0.05 & 1.45 & 39.87 \\
7 & External & Roof_Ins_XPS_8.0 & 0.08 & 2.20 & 44.24 \\
8 & & Roof_Ins_XPS_10.0 & 0.10 & 2.75 & 48.60 \\
\hline 9 & RW (rock wool) & Roof_Ins_RW*33.0 & 0.03 & 0.85 & 39.68 \\
10 & Internal & Roof_Ins_RW*_4.0 & 0.04 & 1.10 & 40.45 \\
11 & & Roof_Ins_RW*_5.0 & 0.05 & 1.40 & 41.49 \\
12 & & Roof_Ins_RW*_6.0 & 0.06 & 1.70 & 43.45 \\
\hline
\end{tabular}


Table 7. Characteristics of window frame materials (WFM).

\begin{tabular}{lllll}
\hline $\mathrm{k}$ & Frame types & Thermal break & $\begin{array}{l}\text { Thermal } \\
\text { Resistance } \\
\left(\mathrm{m}^{2} \mathrm{~K} / \mathrm{W}\right)\end{array}$ & $\begin{array}{l}\text { Cost } \\
\left(€ / \mathrm{m}^{2}\right)\end{array}$ \\
\hline 1 & Aluminium & Yes & 0.313 & 314.91 \\
\hline 2 & Wood & -- & 0.455 & 558.88 \\
\hline 3 & $\begin{array}{l}\text { PVC } \\
\text { (Polyvinyl chloride) }\end{array}$ & -- & 0.455 & 232.35 \\
\hline
\end{tabular}

Table 8. Characteristics of window glass materials (WGM).

\begin{tabular}{llllll}
\hline 1 & Glass types & $\begin{array}{l}\text { Air chamber } \\
\text { thickness }(\mathrm{mm})\end{array}$ & $\begin{array}{l}\text { Thermal Resistance } \\
\left(\mathrm{m}^{2} \mathrm{~K} / \mathrm{W}\right)\end{array}$ & $\begin{array}{l}\text { Solar } \\
\text { factor }\end{array}$ & $\begin{array}{l}\text { Cost } \\
\left(€ / \mathrm{m}^{2}\right)\end{array}$ \\
\hline 1 & Standard & 0.303 & 0.77 & 39.70 \\
\hline 2 & $\begin{array}{l}\text { Low thermal emissivity } \\
\text { (air) }\end{array}$ & 6 & 0.400 & 0.41 & 113.28 \\
\hline 3 & $\begin{array}{l}\text { Low thermal emissivity } \\
\text { (argon) }\end{array}$ & 10 & 0.714 & 0.39 & 120.25 \\
\hline
\end{tabular}

Table 9. Solar protection element for $45^{\circ} \mathrm{N}$ latitude (SPE).

\begin{tabular}{lllll}
\hline $\mathrm{m}$ & Orientation & Inclination & $\begin{array}{l}\text { Shadow } \\
\text { factor }\end{array}$ & $\begin{array}{l}\text { Cost } \\
\left(€ / \mathrm{m}^{2}\right)\end{array}$ \\
\hline 1 & South & $60^{\circ}$ & 0.50 \\
\cline { 3 - 4 } & $180^{\circ}$ (no element) & 0.00 \\
\cline { 1 - 3 } 3 & South East & $60^{\circ}$ & 0.58 \\
\cline { 3 - 4 } & East & $180^{\circ}$ (no element) & 0.00 \\
\cline { 1 - 3 } 5 & South West & $60^{\circ}$ & 0.58 \\
\cline { 3 - 4 } & West & $180^{\circ}$ (no element) & 0.00 \\
\hline
\end{tabular}

\subsection{Results: analysis and discussion}

As Figure 1 shows, before running the optimization process it is necessary to know the building heating and cooling energy demand in its current state. These values are calculated in the developed tool, and in this case they are $87.2 \mathrm{kWh} / \mathrm{m}^{2}$ for heating and 44.7 Kwh/m² for cooling, obtaining a " $\mathrm{G}$ " rating for heating and " $\mathrm{D}$ " for cooling. In this specific case, after the optimization process, an attempt is made to reach the best rating possible on both demands, rated at the same level. In other words, the intention is to reach the point where the demands are optimal with the same energy rating in both cases 
(Table 10). The search for the "A" rating is begun. If this is not reached in both cases, the next step is to study the " $\mathrm{B}$ " rating, and so on.

Table 10. Demand selection criteria used in the case study. Example for the search for the "A" rating

\begin{tabular}{lccc}
\hline Rating & Heating & Cooling & Valid solution? \\
\hline \multirow{3}{*}{$\mathrm{A}$} & $\mathrm{Ok}$ & $\mathrm{No}$ & No \\
\cline { 2 - 3 } & $\mathrm{No}$ & $\mathrm{Ok}$ & \\
\cline { 2 - 4 } & $\mathrm{Ok}$ & $\mathrm{Ok}$ & Yes \\
\hline
\end{tabular}

Table 11 indicates the configuration given of the parameters of the GA used in each of the optimizations performed.

Table 11. Evolutionary Solver Parameters.

\begin{tabular}{ll}
\hline Precision of the restrictions & 0.0001 \\
\hline Convergence & 0.1 \\
\hline Size of the population & 700 \\
\hline Rate of mutation & 0.075 \\
\hline Random initialization value & 0 \\
\hline Maximum time without improvement & 300 \\
\hline
\end{tabular}

The value used for the population size, greater than normal in these cases, stems from the extensive sample space that contemplates the problem ( $2^{36}$ options). On the one hand, the convergence precision is due to the fact that the goal is to optimize the economic cost, so that a more sensitive convergence would not make sense. The value given to the other Solver configuration options (precision of the restrictions, rate of mutation, random initialization value, and maximum time without improvement) are taken based on successive optimization cycles, with those shown in table 11 providing the best results in computational terms.

In a first step, two optimizations were performed, the first taking into account only the restrictions derived from adjusting the heating demand and the second referring to the cooling demand. If solutions are found for each of these, a third optimization is carried out taking both restrictions into account.

The values taken as limits for the ratings on both demands are established according to the climate zone where the building is located. In our case, as it is located in Sevilla, the value limits are those applicable to zone B4 (Table 4). 
The calculation procedure begins by adjusting both demands separately to the "A" rating (OPT 1). Forcing the heating demand, we only find 6 feasible configurations, while there are no solutions for the fit of the cooling demand, so that there is no compatible solution. Of the 6 options that meet the restrictions for the heating demand, the optimized one is number 6 , with a necessary investment of $8854.07 €$. Table 12 shows the configuration of each of the compatible solutions, while Figure 3 represents the heating demand for each solution in relation to the necessary investment to reach it. As we can see, solution 1 shows the greatest energy savings, but its cost is too high. In the solution we consider optimal, the energy savings is less (we are not optimizing), but the desired rating is reached with the minimum cost (optimized value).

Table 12. Solutions to OPT 1.

\begin{tabular}{|c|c|c|c|c|c|c|c|c|c|}
\hline & $\begin{array}{l}\text { Cost } \\
(€)\end{array}$ & $\begin{array}{l}\text { Energy saving } \\
\text { (kWh/year) }\end{array}$ & $\begin{array}{l}\text { Heating energy } \\
\text { demand }\left(\mathrm{kWh} / \mathrm{m}^{2}\right)\end{array}$ & $\begin{array}{l}\text { Cooling energy } \\
\text { demand }\left(\mathrm{kWh} / \mathrm{m}^{2}\right)\end{array}$ & WIM & RIM & WFM & WGM & SPE \\
\hline 1 & 9992.27 & 8508.50 & $6.9(\mathrm{~A})$ & $31.5(\mathrm{D})$ & 8 & 7 & 3 & 3 & $2-4-6$ \\
\hline 2 & 9920.80 & 8353.80 & $7.6(\mathrm{~A})$ & 32.5 (D) & 8 & 12 & 3 & 3 & $2-4-6$ \\
\hline 3 & 9742.02 & 8244.60 & $8.1(\mathrm{~A})$ & 33.2 (D) & 8 & 11 & 3 & 3 & $2-4-6$ \\
\hline 4 & 9594.60 & 8262.80 & 8.0 (A) & 33.1 (D) & 8 & 6 & 3 & 3 & $2-4-6$ \\
\hline 5 & 9051.52 & 8435.70 & $7.6(\mathrm{~A})$ & 31.6 (D) & 12 & 7 & 3 & 3 & $2-4-6$ \\
\hline 6 & 8854.07 & 8271.90 & 8.0 (A) & 33.0 (D) & 3 & 6 & 3 & 3 & $2-4-6$ \\
\hline
\end{tabular}

Each optimal solution for the energy demand level is in bold italics.

Figure 3. Solutions for the building retrofit strategies (Heating, level A) - OPT 1.

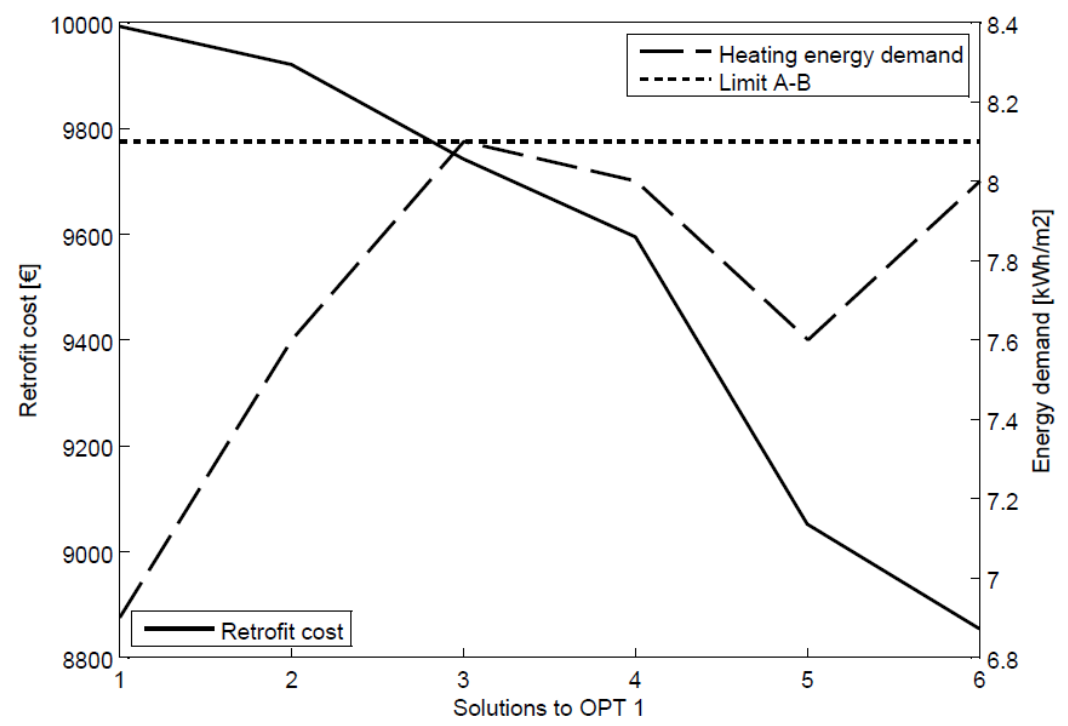

Next, the demands are forced separately to reach the "B" rating. In this case, we find solutions for both cases, shown in Tables 13 - 14 and Figures $4-5$, for heating (OPT 2) 
and cooling (OPT 3), respectively. Given that there are independent solutions to fit the demands, the next step is to launch the joint optimization of both demands (OPT 4), whose results are shown in Figure 6 and Table 15.

Figure 4. Solutions for the building retrofit strategies (Heating, level B) - OPT 2.

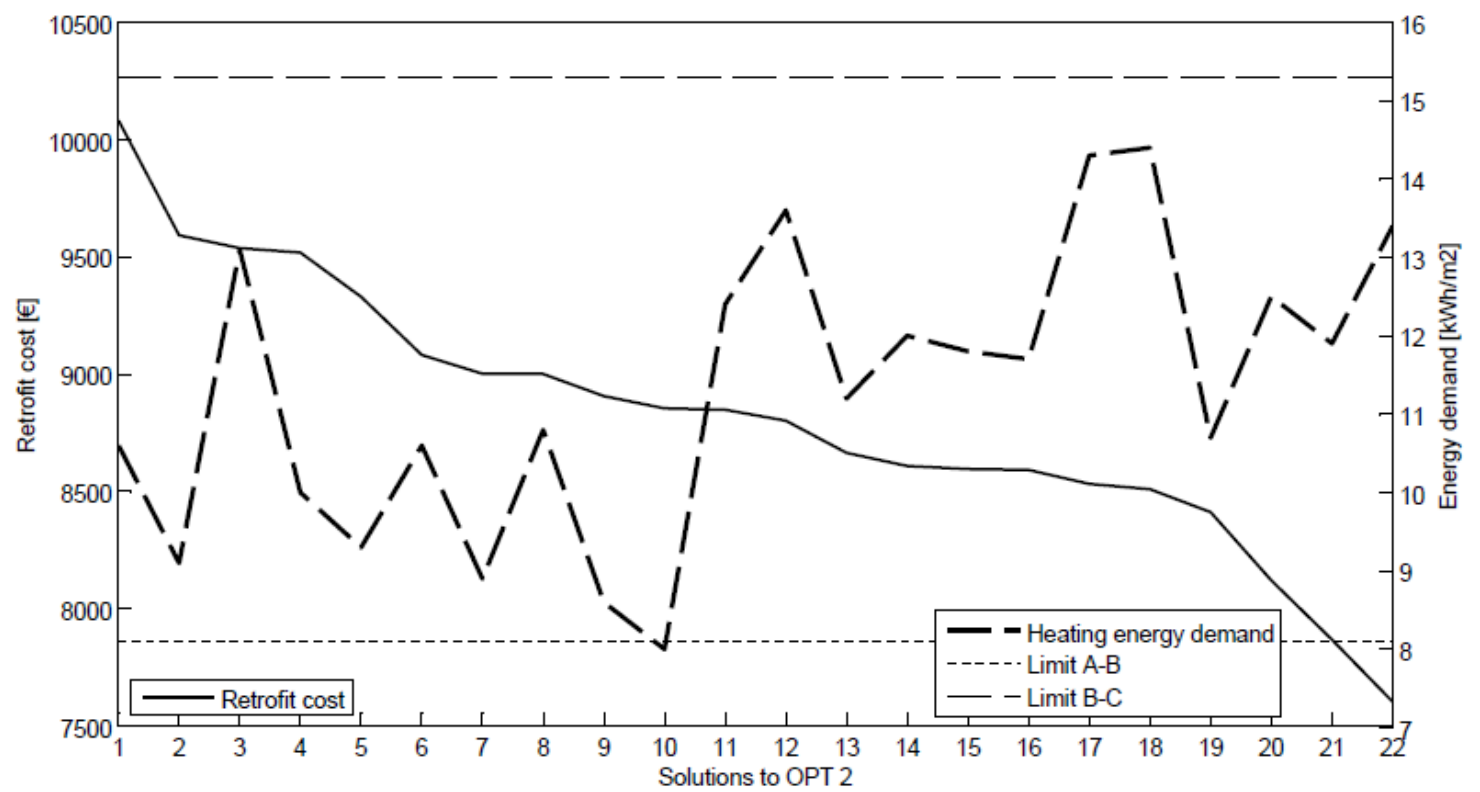

Table 13. Solutions to OPT 2.

\begin{tabular}{|c|c|c|c|c|c|c|c|c|c|}
\hline & $\begin{array}{l}\text { Cost } \\
(€)\end{array}$ & $\begin{array}{l}\text { Energy saving } \\
\text { (kWh/year) }\end{array}$ & $\begin{array}{l}\text { Heating energy } \\
\text { demand }\left(\mathrm{kWh} / \mathrm{m}^{2}\right)\end{array}$ & $\begin{array}{l}\text { Cooling energy } \\
\text { demand }\left(\mathrm{kWh} / \mathrm{m}^{2}\right)\end{array}$ & WIM & RIM & WFM & WGM & SPE \\
\hline 1 & 10081.20 & 7998.90 & $10.6(\mathrm{~B})$ & $33.4(\mathrm{D})$ & 6 & 6 & 2 & 3 & $2-4-6$ \\
\hline 2 & 9591.65 & 8199.10 & $9.1(\mathrm{~B})$ & 32.7 (D) & 7 & 12 & 3 & 3 & $2-4-6$ \\
\hline 3 & 9537.57 & 7853.30 & 13.1 (B) & 32.5 (D) & 7 & 2 & 3 & 1 & $2-4-6$ \\
\hline 4 & 9518.50 & 8071.70 & $10.0(\mathrm{~B})$ & 33.2 (D) & 7 & 6 & 1 & 3 & $2-4-6$ \\
\hline 5 & 9329.79 & 7989.80 & 9.3 (B) & 34.8 (D) & 8 & 5 & 3 & 3 & $2-4-6$ \\
\hline 6 & 9081.98 & 7998.90 & $10.6(\mathrm{~B})$ & 33.4 (D) & 6 & 6 & 3 & 3 & $2-4-6$ \\
\hline 7 & 9002.35 & 8217.30 & $8.9(\mathrm{~B})$ & 32.7 (D) & 2 & 12 & 3 & 3 & $2-4-6$ \\
\hline 8 & 9001.06 & 7835.10 & $10.8(\mathrm{~B})$ & 35.0 (D) & 7 & 5 & 3 & 3 & $2-4-6$ \\
\hline 9 & 8906.85 & 8135.40 & 8.6 (B) & 33.9 (D) & 3 & 10 & 3 & 3 & $2-4-6$ \\
\hline 10 & 8866.62 & 7580.30 & $15.8(\mathrm{~B})$ & 32.8 (D) & 1 & 2 & 3 & 1 & $2-4-6$ \\
\hline 11 & 8847.55 & 7826.00 & $12.4(\mathrm{~B})$ & 33.5 (D) & 1 & 6 & 1 & 3 & $2-4-6$ \\
\hline 12 & 8801.40 & 7698.60 & $13.6(\mathrm{~B})$ & 33.7 (D) & 9 & 6 & 1 & 3 & $2-4-6$ \\
\hline 13 & 8664.39 & 7807.80 & $11.2(\mathrm{~B})$ & 34.9 (D) & 2 & 5 & 1 & 3 & $2-4-6$ \\
\hline 14 & 8608.68 & 7907.90 & 12.0 (B) & 33.0 (D) & 8 & 6 & 3 & 1 & $2-4-6$ \\
\hline 15 & 8594.92 & 7880.60 & $11.8(\mathrm{~B})$ & 33.5 (D) & 1 & 6 & 3 & 3 & $2-4-6$ \\
\hline 16 & 8591.26 & 7917.00 & $11.7(\mathrm{~B})$ & 33.2 (D) & 2 & 6 & 3 & 2 & $2-4-6$ \\
\hline 17 & 8532.58 & 7680.40 & $14.3(\mathrm{~B})$ & 33.2 (D) & 7 & 6 & 1 & 1 & $2-4-6$ \\
\hline 18 & 8509.61 & 7644.00 & 14.4 (B) & 33.5 (D) & 1 & 6 & 3 & 2 & $2-4-6$ \\
\hline
\end{tabular}


Table 13. Continuation.

\begin{tabular}{|c|c|c|c|c|c|c|c|c|c|}
\hline & $\begin{array}{l}\text { Cost } \\
(€)\end{array}$ & $\begin{array}{l}\text { Energy saving } \\
\text { (kWh/year) }\end{array}$ & $\begin{array}{l}\text { Heating energy } \\
\text { demand }\left(\mathrm{kWh} / \mathrm{m}^{2}\right)\end{array}$ & $\begin{array}{l}\text { Cooling energy } \\
\text { demand }\left(\mathrm{kWh} / \mathrm{m}^{2}\right)\end{array}$ & WIM & RIM & WFM & WGM & SPE \\
\hline 19 & 8411.76 & 7853.30 & $10.7(\mathrm{~B})$ & 34.9 (D) & 2 & 5 & 3 & 3 & $2-4-6$ \\
\hline 20 & 8120.78 & 7862.40 & $12.5(\mathrm{~B})$ & 33.0 (D) & 3 & 6 & 1 & 1 & $2-4-6$ \\
\hline 21 & 7868.15 & 7917.00 & $11.9(\mathrm{~B})$ & 33.0 (D) & 3 & 6 & 3 & 1 & $2-4-6$ \\
\hline 22 & 7603.34 & 7625.80 & 13.4 (B) & 34.7 (D) & 3 & 5 & 3 & 1 & $2-4-6$ \\
\hline
\end{tabular}

Each optimal solution for the energy demand level is in bold italics.

Figure 5. Solutions for the building retrofit strategies (Cooling, level B) - OPT 3.

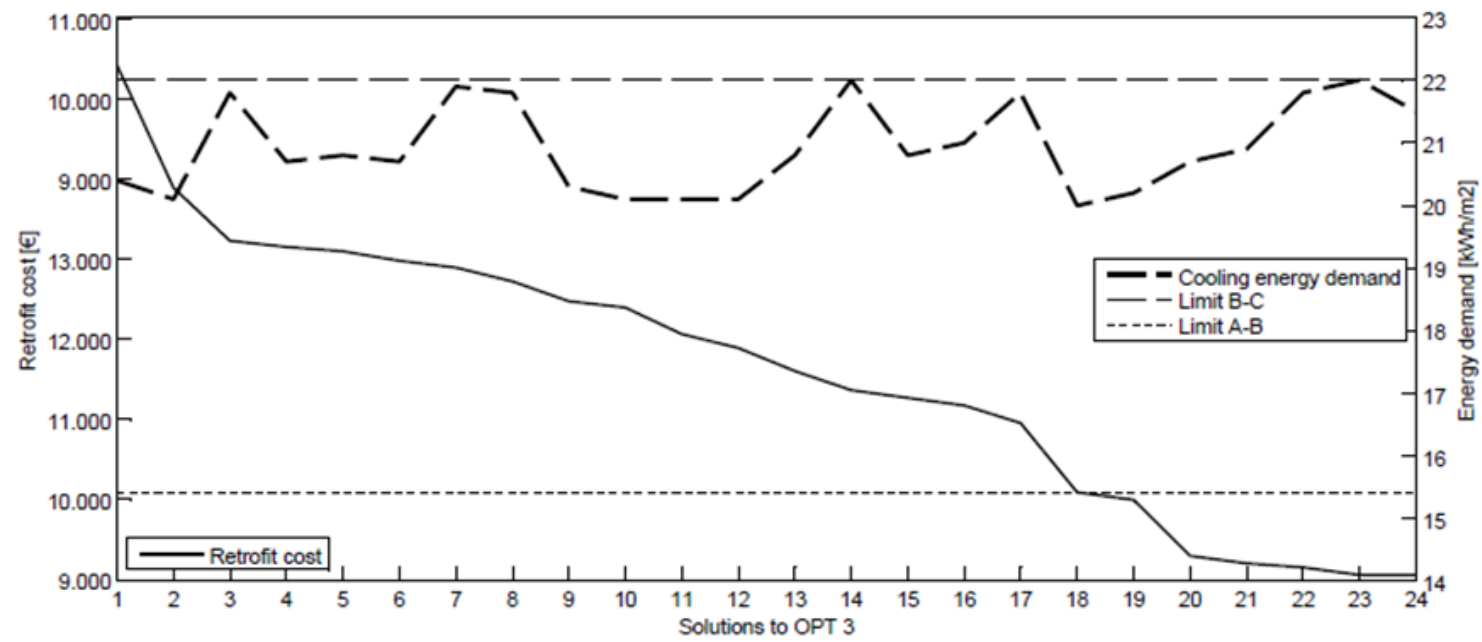

Table 14. Solutions to OPT 3.

\begin{tabular}{|c|c|c|c|c|c|c|c|c|c|}
\hline & $\begin{array}{l}\text { Cost } \\
(€)\end{array}$ & $\begin{array}{l}\text { Energy saving } \\
\text { (kWh/year) }\end{array}$ & $\begin{array}{l}\text { Heating energy } \\
\text { demand }\left(\mathrm{kWh} / \mathrm{m}^{2}\right)\end{array}$ & $\begin{array}{l}\text { Cooling energy } \\
\text { demand }\left(\mathrm{kWh} / \mathrm{m}^{2}\right)\end{array}$ & WIM & RIM & WFM & WGM & SPE \\
\hline 1 & 12710.10 & 8490.30 & $18.2(\mathrm{C})$ & 20.4 (B) & 4 & 11 & 1 & 2 & $1-3-5$ \\
\hline 2 & 11946.30 & 8754.20 & $15.6(\mathrm{C})$ & 20.1 (B) & 8 & 12 & 2 & 2 & $1-3-5$ \\
\hline 3 & 11615.40 & 8235.50 & $19.6(\mathrm{C})$ & 21.8 (B) & 2 & 11 & 1 & 2 & $1-3-5$ \\
\hline 4 & 11576.40 & 8999.90 & $12.3(\mathrm{~B})$ & 20.7 (B) & 7 & 8 & 3 & 3 & $1-3-5$ \\
\hline 5 & 11549.50 & 8626.80 & $16.3(\mathrm{C})$ & 20.8 (B) & 7 & 12 & 2 & 2 & $1-3-5$ \\
\hline 6 & 11491.10 & 8726.90 & $15.3(\mathrm{~B})$ & 20.7 (B) & 7 & 8 & 3 & 2 & $1-3-5$ \\
\hline 7 & 11448.10 & 8590.40 & $15.6(\mathrm{C})$ & 21.9 (B) & 2 & 11 & 3 & 3 & $1-3-5$ \\
\hline 8 & 11362.70 & 8299.20 & $18.9(\mathrm{C})$ & 21.8 (B) & 2 & 11 & 3 & 2 & $1-3-5$ \\
\hline 9 & 11237.50 & 8808.80 & $14.8(\mathrm{~B})$ & $20.3(\mathrm{~B})$ & 8 & 11 & 1 & 3 & $1-3-5$ \\
\hline 10 & 11199.80 & 8690.50 & $16.3(\mathrm{C})$ & 20.1 (B) & 8 & 12 & 1 & 2 & $1-3-5$ \\
\hline 11 & 11032.40 & 9036.30 & $12.5(\mathrm{~B})$ & $20.1(B)$ & 8 & 12 & 3 & 3 & $1-3-5$ \\
\hline 12 & 10947.10 & 8754.20 & $15.6(\mathrm{C})$ & 20.1 (B) & 8 & 12 & 3 & 2 & $1-3-5$ \\
\hline 13 & 10803.00 & 8563.10 & $17.0(\mathrm{C})$ & 20.8 (B) & 7 & 12 & 1 & 2 & $1-3-5$ \\
\hline 14 & 10683.50 & 8199.10 & $19.8(\mathrm{C})$ & 22.0 (B) & 12 & 11 & 1 & 2 & $1-3-5$ \\
\hline 15 & 10635.70 & 8908.90 & $13.2(\mathrm{~B})$ & 20.8 (B) & 7 & 12 & 3 & 3 & $1-3-5$ \\
\hline 16 & 10588.10 & 8745.10 & $14.8(\mathrm{~B})$ & 21.0 (B) & 7 & 11 & 3 & 3 & $1-3-5$ \\
\hline 17 & 10478.50 & 8448.80 & $17.3(\mathrm{C})$ & $21.8(\mathrm{~B})$ & 12 & 12 & 3 & 2 & $1-3-5$ \\
\hline
\end{tabular}


Table 14. Continuation.

\begin{tabular}{llllllllll}
\hline & $\begin{array}{l}\text { Cost } \\
(€)\end{array}$ & $\begin{array}{l}\text { Energy saving } \\
(\mathrm{kWh} / \mathrm{year})\end{array}$ & $\begin{array}{l}\text { Heating energy } \\
\text { demand }\left(\mathrm{kWh} / \mathrm{m}^{2}\right)\end{array}$ & $\begin{array}{l}\text { Cooling energy } \\
\text { demand }\left(\mathrm{kWh} / \mathrm{m}^{2}\right)\end{array}$ & WIM & RIM & WFM & WGM & SPE \\
\hline 18 & 10046.50 & 8544.90 & $18.0(\mathrm{C})$ & $\mathbf{2 0 . 0}(\mathbf{B})$ & 12 & 8 & 3 & 1 & $1-3-5$ \\
\hline 19 & 9998.94 & 8362.90 & $19.8(\mathrm{C})$ & $\mathbf{2 0 . 2}(\mathbf{B})$ & 11 & 8 & 3 & 1 & $1-3-5$ \\
\hline 20 & 9649.75 & 8417.50 & $18.7(\mathrm{C})$ & $\mathbf{2 0 . 7}(\mathbf{B})$ & 12 & 7 & 3 & 1 & $1-3-5$ \\
\hline 21 & 9602.18 & 8235.50 & $20.5(\mathrm{C})$ & $\mathbf{2 0 . 9}(\mathbf{B})$ & 11 & 7 & 3 & 1 & $1-3-5$ \\
\hline 22 & 9577.86 & 8226.40 & $19.7(\mathrm{C})$ & $\mathbf{2 1 . 8}(\mathbf{B})$ & 12 & 12 & 3 & 1 & $1-3-5$ \\
\hline 23 & 9530.29 & 8044.40 & $21.5(\mathrm{C})$ & $\mathbf{2 2 . 0}(\mathbf{B})$ & 11 & 12 & 3 & 1 & $1-3-5$ \\
\hline 24 & $\mathbf{9 5 2 8 . 3 4}$ & 7589.40 & $27.0(\mathrm{D})$ & $\mathbf{2 1 . 5}(\mathbf{B})$ & 4 & 7 & 3 & 1 & $1-3-5$ \\
\hline
\end{tabular}

Each optimal solution for the energy demand level is in bold italics.

Figure 6. Solutions for the building retrofit strategies (Heating and Cooling, level B) - OPT 4.

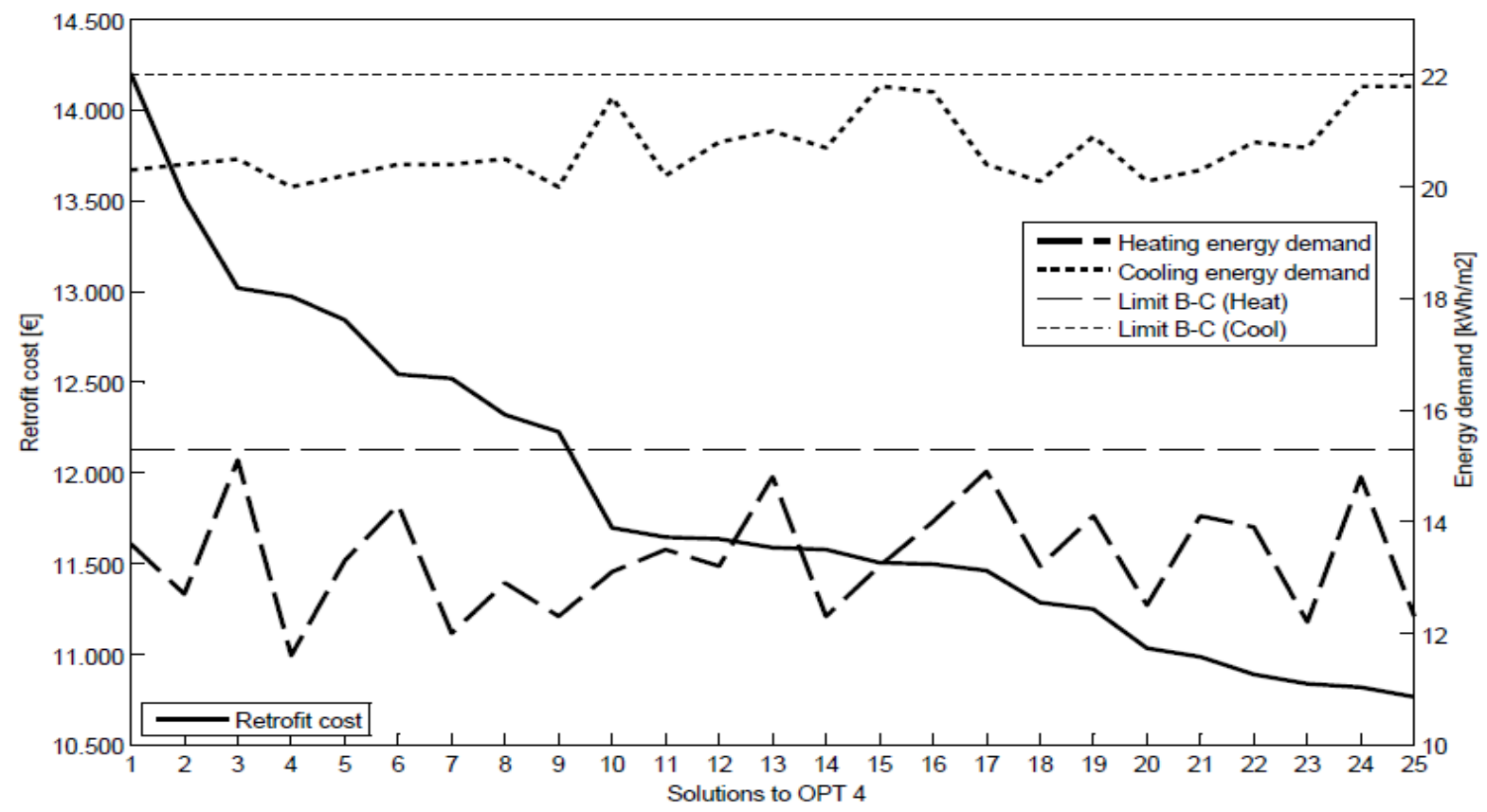

Table 15. Solutions to OPT 4.

\begin{tabular}{|c|c|c|c|c|c|c|c|c|c|}
\hline & $\begin{array}{l}\text { Cost } \\
(€)\end{array}$ & $\begin{array}{l}\text { Energy saving } \\
\text { (kWh/year) }\end{array}$ & $\begin{array}{l}\text { Heating energy } \\
\text { demand }\left(\mathrm{kWh} / \mathrm{m}^{2}\right)\end{array}$ & $\begin{array}{l}\text { Cooling energy } \\
\text { demand }\left(\mathrm{kWh} / \mathrm{m}^{2}\right)\end{array}$ & WIM & RIM & WFM & WGM & SPE \\
\hline 1 & 14201.60 & 8918.00 & 13.6 (B) & $20.3(B)$ & 7 & 4 & 2 & 3 & $1-3-5$ \\
\hline 2 & 13512.60 & 8990.80 & 12.7 (B) & 20.4 (B) & 8 & 3 & 1 & 3 & $1-3-5$ \\
\hline 3 & 13018.50 & 8763.30 & 15.1 (B) & $20.5(B)$ & 6 & 4 & 3 & 3 & $1-3-5$ \\
\hline 4 & 12972.40 & 9127.30 & 11.6 (B) & 20.0 (B) & 8 & 8 & 2 & 3 & $1-3-5$ \\
\hline 5 & 12843.00 & 8954.40 & 13.3 (B) & 20.2 (B) & 12 & 4 & 1 & 3 & $1-3-5$ \\
\hline 6 & 12542.80 & 8845.20 & 14.3 (B) & 20.4 (B) & 11 & 4 & 3 & 3 & $1-3-5$ \\
\hline 7 & 12519.40 & 9054.50 & 12.0 (B) & 20.4 (B) & 3 & 3 & 3 & 3 & $1-3-5$ \\
\hline 8 & 12319.20 & 8963.50 & $12.9(\mathrm{~B})$ & $20.5(B)$ & 12 & 3 & 3 & 3 & $1-3-5$ \\
\hline 9 & 12225.80 & 9063.60 & $12.3(\mathrm{~B})$ & 20.0 (B) & 8 & 8 & 1 & 3 & $1-3-5$ \\
\hline 10 & 11695.80 & 8845.20 & 13.1 (B) & $21.6(B)$ & 2 & 2 & 3 & 3 & $1-3-5$ \\
\hline
\end{tabular}


Table 15. Continuation.

\begin{tabular}{|c|c|c|c|c|c|c|c|c|c|}
\hline & $\begin{array}{l}\text { Cost } \\
(€)\end{array}$ & $\begin{array}{l}\text { Energy saving } \\
\text { (kWh/year) }\end{array}$ & $\begin{array}{l}\text { Heating energy } \\
\text { demand }\left(\mathrm{kWh} / \mathrm{m}^{2}\right)\end{array}$ & $\begin{array}{l}\text { Cooling energy } \\
\text { demand }\left(\mathrm{kWh} / \mathrm{m}^{2}\right)\end{array}$ & WIM & RIM & WFM & WGM & SPE \\
\hline 11 & 11644.50 & 8936.20 & 13.5 (B) & 20.2 (B) & 8 & 8 & 3 & 3 & $1-3-5$ \\
\hline 12 & 11634.90 & 8908.90 & 13.2 (B) & 20.8 (B) & 7 & 7 & 2 & 3 & $1-3-5$ \\
\hline 13 & 11587.30 & 8745.10 & $14.8(B)$ & 21.0 (B) & 7 & 7 & 2 & 3 & $1-3-5$ \\
\hline 14 & 11576.40 & 8999.90 & 12.3 (B) & 20.7 (B) & 7 & 7 & 3 & 3 & $1-3-5$ \\
\hline 15 & 11504.50 & 8817.90 & 13.2 (B) & 21.8 (B) & 12 & 12 & 3 & 3 & $1-3-5$ \\
\hline 16 & 11495.60 & 8754.20 & 14.0 (B) & $21.7(\mathrm{~B})$ & 2 & 2 & 3 & 3 & $1-3-5$ \\
\hline 17 & 11460.60 & 8790.60 & 14.9 (B) & 20.4 (B) & 8 & 8 & 3 & 3 & $1-3-5$ \\
\hline 18 & 11285.10 & 8972.60 & $13.2(\mathrm{~B})$ & $20.1(B)$ & 12 & 8 & 1 & 3 & $1-3-5$ \\
\hline 19 & 11247.70 & 8817.90 & 14.1 (B) & 20.9 (B) & 7 & 7 & 3 & 3 & $1-3-5$ \\
\hline 20 & 11032.40 & 9036.30 & $12.5(\mathrm{~B})$ & 20.1 (B) & 12 & 8 & 3 & 3 & $1-3-5$ \\
\hline 21 & 10984.90 & 8872.50 & 14.1 (B) & 20.3 (B) & 11 & 8 & 3 & 3 & $1-3-5$ \\
\hline 22 & 10888.30 & 8845.20 & 13.9 (B) & 20.8 (B) & 12 & 7 & 1 & 3 & $1-3-5$ \\
\hline 23 & 10835.90 & 9009.00 & $12.2(\mathrm{~B})$ & $20.7(B)$ & 3 & 7 & 3 & 3 & $1-3-5$ \\
\hline 24 & 10816.40 & 8672.3 & $14.8(B)$ & 21.8 (B) & 12 & 12 & 1 & 3 & $1-3-5$ \\
\hline 25 & 10764.00 & 8899.8 & $12.3(\mathrm{~B})$ & 21.8 (B) & 3 & 12 & 3 & 3 & $1-3-5$ \\
\hline
\end{tabular}

Each optimal solution for the energy demand level is in bold italics.

Table 16 shows the results of the optimizations, as well as the final configuration of the energy building retrofit strategies selected.

Table 16. Solutions that optimize each optimization.

\begin{tabular}{|c|c|c|c|c|c|c|c|c|c|}
\hline & $\begin{array}{l}\text { Cost } \\
(€)\end{array}$ & $\begin{array}{l}\text { Energy saving } \\
\text { (kWh/year) }\end{array}$ & $\begin{array}{l}\text { Heating energy } \\
\text { demand }\left(\mathrm{kWh} / \mathrm{m}^{2}\right)\end{array}$ & $\begin{array}{l}\text { Cooling energy } \\
\text { demand }\left(\mathrm{kWh} / \mathrm{m}^{2}\right)\end{array}$ & WIM & RIM & WFM & WGM & SPE \\
\hline OPT 1 & 8854.07 & 8271.90 & $8.0(\mathrm{~A})$ & 33.0 (D) & 3 & 6 & 3 & 3 & $2-4-6$ \\
\hline OPT 2 & 7603.34 & 7625.80 & 13.4 (B) & 34.7 (D) & 3 & 5 & 3 & 1 & $2-4-6$ \\
\hline OPT 3 & 9528.34 & 7589.40 & 27.0 (D) & $21.5(\mathrm{~B})$ & 4 & 7 & 3 & 1 & $1-3-5$ \\
\hline OPT 4 & 10764.0 & 8899.80 & $12,3(\mathrm{~B})$ & $21.8(\mathrm{~B})$ & 3 & 12 & 3 & 3 & $1-3-5$ \\
\hline
\end{tabular}

Each optimal solution for the energy demand level is in bold italics.

The lowest computational calculation time was for OPT 1: 10 minutes; while the greatest was for OPT 4: 20 minutes.

When the cooling energy demand is not taken into account in the optimization, no solar protection element is selected. The opposite occurs when the cooling energy demand enters the picture, where, whether or not the heating energy demand is taken into account, solar protections are selected for all the facades. Another common factor in all the 
optimizations is the window frame material, with the PVC option being the most feasible in all of them.

The best possible solution in terms of overall energy savings is OPT 4, where heating and cooling demands are adjusted to the B rating, obtaining a savings of $8899.80 \mathrm{kWh} / \mathrm{year}$.

As Tables $12-16$ and Figures 3 - 6 show, the proposed process does not focus on energy saving, but rather on the rating obtained, as this is its objective.

The results obtained from the application of the proposed approach to calculate the solutions for the case study show the viability of this methodology as a tool to support the search for balanced strategies to retrofit existing buildings.

\section{Conclusions and future work}

One of the main problems in checking an energy retrofit of an existing building is the selection of the most beneficial measures among a large number of possibilities derived from a heterogeneous set of materials with very different characteristics applied to different purposes. This problem can be resolved by using a multi-criteria approach that takes into account the possible intrinsic restrictions, as well as the influences among them, but it could become inefficient in its computational calculation.

In this study, a mono-criterion optimization process based on a combination of MS Excel and GA is presented. The method is aimed to reach a particular energy efficiency rating of the energy demand for cooling and heating. The main objective is the minimization of energy retrofit cost. Other possible objectives, such as the adjustment of energy demand, are configured as constraints.

The simplicity of the implementation of the method developed makes it a product with great potential for use in its field of application. In future developments, the tool will be configured as an open complement of MS Excel, thus fostering its distribution.

The proposed approach was applied to an existing case study, and the results show its viability for providing support for decisions in a real setting, simultaneously considering all the possible alternatives. Furthermore, with this methodology we were able to minimize the computational cost and calculation time of the process compared to complex energy simulation programs and multi-criteria optimization problem, thus giving it a more versatile nature. 
In future studies, it would be interesting to include constraints related to the indoor thermal comfort or indoor air quality, along with those applied in this study, in order to achieve a greater scope of action for the technique.

\section{References}

[1] Eurostat. EU25 energy consumption equivalent to more than three and a half tonnes of oil per capita. News Release 2006; 126.

[2] European Union. Directive 2010/31/EU of the European Parliament and of the Council of 19 May 2010 on the Energy Performance of Buildings. Official J Eur Union 2010; 153: 13-15.

[3] European Union. Directive 2002/91/CE of the European Parliament and of the Council of 16 December 2002 on the energy performance of buildings. Official J Eur Communities 2003; 1: 65-71.

[4] Erlandsson M and Borg M. Generic LCA - methodology applicable for building, construction and operation services - today practice and development needs. Build Environ 2003; 38: 919-938.

[5] International Panel of Climate Change. Mitigation of climate change contribution of working group III to the fourth assessment report of the intergovernmental panel on climate. Cambridge: Cambridge University Press, 2007.

[6] Asadi E, Da Silva MG, Antunes CH, et al. A multiobjective optimization model for building retrofit strategies using TRNSYS simulations, GenOpt and MATLAB. Build Environ 2012; 56: 370-378.

[7] Holm MG. Service management in housing refurbishment: a theoretical approach. Constr Manage Econ 2000; 18: 525-533.

[8] Attia S, Hamdyc M, O'Briend W, et al. Assessing gaps and needs for integrating building performance optimization tools in net zero energy buildings design. Energ Build 2013; 60: 110-124.

[9] Juan Y, Ha Kim J, Roper K, et al. GA-based decision support system for housing condition assessment and refurbishment strategies. Autom Constr 2009; 18: 394-401.

[10] Evins R. A review of computational optimization methods applied to sustainable building design. Renew Sustain Energ Rev 2013; 22: 230-245. 
[11] Hooke R and Jeeves TA. Direct search solution of numerical and statistical problems. J ACM 1961; 8: 212-229.

[12] Nelder JA and Mead R. A simplex method for function minimization. Comput J 1965; 7: 308-313. [13] Goldberg DE. Genetic algorithms in search, optimization and machine learning, 1st ed. Boston: Addison-Wesley Professional, 1989.

[14] Fogel LJ. Intelligence through simulated evolution: forty years of evolutionary programming. New York: John Wiley \& Sons, 1999.

[15] Sette S and Boullart L. Genetic programming: principles and applications. Eng Appl Artif Intell 2001; 14: 727-736.

[16] Hansen $\mathrm{N}$ and Ostermeier A. Adapting arbitrary normal mutation distributions in evolution strategies: the covariance matrix adaptation. In: Proceedings of IEEE international conference on evolutionary computation, Nagoya, Japan, 20-22 May 1996, paper no. 0-7803-2902-3,pp. 312-317. New Jersey: IEEE.

[17] Storn R and Price K. Differential evolution - a simple and efficient heuristic for global optimization over continuous spaces. J Global Optim 1997; 11: 341-359.

[18] Geem ZW, Kim JH and Loganathan G. A new heuristic optimization algorithm: harmony search. Simulation 2001; 76: 60-68.

[19] Kennedy J and Eberhart R. Particle swarm optimization. In: Proceedings of IEEE international conference on neural networks vol. 4, Perth, Australia, Nov/Dec 1995, paper no. 0-7803-2768-3, pp. 1942-1948. Perth: IEEE.

[20] Dorigo M, Maniezzo V and Colorni A. The ant system: optimization by a colony of cooperating agents. Proc IEEE Trans Syst Man Cybern B 1996; 26: 29-41.

[21] Kirkpatrick S, Gelatt CD and Vecchi MP. Optimization by simulated annealing. Science 1983; 220: 671-680. [22] Machairas V, Tsangrassoulis A and Axarli K. Algorithms for optimization of building design: a review. Renew Sustain Energ Rev 2014; 31: 101-112.

[23] Znouda E, Ghrab-Morcos N and Hadj-Alouane A. Optimization of Mediterranean building design using genetic algorithms. Energ Build 2007; 39: 148-153.

[24] Rakh T and Nassar K. Genetic algorithms for ceiling form optimization in response to daylight levels. Renew Energ 2011; 36: 2348-2356. 
[25] Coley D and Shukat S. Low-energy design: combining computer-based optimization and human judgement. Build Environ 2002; 37: 1241-1247.

[26] Manzan M and Pinto F. Genetic optimization of external shading devices. In: Eleventh international IBPSA conference, Glasgow, UK, 2009.

[27] Sahu M, Bhattacharjee B and Kaushik S. Thermal design of air-conditioned buildings for tropical climate using admittance method and genetic algorithm. Energ Build 2012; 53: 1-6.

[28] Jin Q and Overend M. Facade renovation for a public building based on a whole-life value approach. In: Building simulation and optimization conference, Loughborough, UK, 2012.

[29] Malatji EM, Zhang J and Xia X. A multiple objective optimization model for building energy efficiency investment decision. Energ Build 2013; 61: 81-87.

[30] Shao Y, Geyer P and Lang W. Integrating requirement analysis and multi-objective optimization for office building energy retrofit strategies. Energ Build 2014; 82: 356368.

[31] Shao Y, Geyer P and Lang W. Integrating requirement analysis and multi-objective optimization for office building energy retrofit strategies. Energ Build 2014; 82: 356368.

[32] Microsoft Office Excel, http://blogs.office.com/2009/09/ 21/new-and-improvedsolver/ (2014, accessed 29 March 2016).

[33] ISO 13790:2008. Energy performance of buildings - calculation of energy use for space heating and cooling.

[34] EN 15217:2012. Energy performance of buildings - methods for expressing energy performance and for the energy certification of buildings.

[35] Frontline Solvers, http://goo.gl/Fmcb8Z (accessed 29

March 2016).

[36] Diakaki C, Evangelos G and Kolokotsa D. Towards a multi-objective optimization approach for improving energy efficiency in building. Energ Build 2008; 40: 1747-1754.

[37] Diakaki C, Evangelos G, Kabelis N, et al. A multiobjective decision model for the improvement of energy efficiency in buildings. Energy 2010; 35: 5483-5496. 
[38] Spain. RD 314/2006, of 17 March 2006, Codigo Tecnico de la Edificacion. BOE 2006; 74.

[39] ISO 9001:2008. CYPE Ingenieros. Software for architecture, engineering \& construction. 